\title{
Superior vs. Inferior Voting Shares: Price Premium or Discount?
}

\author{
Yan He \\ Indiana University Southeast, Indiana, U.S.A. \\ Junbo Wang \\ City University of Hong Kong, Hong Kong, China \\ Chunchi Wu \\ State University of New York at Buffalo, New York, U.S.A.
}

\begin{abstract}
This paper analyzes the price difference between superior voting (SV) and inferior voting (IV) shares for three dual-class firms: Farmer Mac as a big price discount case, Fox as a price similarity case, and Heico as a big price premium case. We show that the price difference is mainly affected by the control benefit, while voting power and liquidity are also relevant factors. We suggest that the control benefit can be revealed by examining share accumulation and firm performance.
\end{abstract}

Keywords: superior voting (SV), inferior voting (IV), price premium, price discount, dual classes

\section{Introduction}

Most publicly traded companies in the U.S. have a single class of common stock, while others have dual or multiple classes. A typical dual-class firm issues two classes of common stock shares: the superior voting (SV) class, and the inferior voting (IV) or restricted voting (RV) class. The SV has full or concentrated votes, and the IV, diluted votes or no vote at all. About $6 \%$ of U.S. firms, 30\% of British firms, and $10 \%$ of Canadian firms have a dual-class structure. ${ }^{1}$ Among the initial public offerings (IPOs) on U.S. exchanges, more than 13.5\% in 2015 have a dual-class structure, $12 \%$ in 2014, and 1\% in 2005. ${ }^{2}$ As H. DeAngelo and L. DeAngelo (1985) stated, the dual-class ownership is an intermediate organizational structure which fits somewhere between the polar cases of the dispersed-ownership public corporation and the closely held firm. According to Smart and Zutter (2003), acquisitions within five years of the IPO occur more frequently for single-class firms than for duals. Therefore, the dual-class structure arises primarily as control-protection or anti-takeover devices.

Usually, SV shares are not publicly listed or traded. For instance, when some social media firms (including Facebook, Zynga, and Groupon) went through a dual-share IPO during 2011-2012, their SV shares were held privately and their IV shares were traded publicly. Such a dual-class structure is described as a two-edged sword. ${ }^{3}$ On the one hand, it may entrench management, leading to a negative effect on the company's value. On the other hand, it may allow management to ignore short-term market pressures and withstand takeover attacks in order to make risky investments for the long term.

Yan He, Associate Professor, School of Business, Indiana University Southeast. Email: yanhe@ius.edu. Junbo Wang, Professor, Department of Economics and Finance, City University of Hong Kong.

Chunchi Wu, M\&T Professor of Banking and Finance, Finance Department, State University of New York at Buffalo.

1 See Smart and Zutter (2003), Loughran and Ritter (2004), Howell (2008), and Gompers, Ishii, and Metrick (2010) for the U.S.

firms, Megginson (1990) for the British firms, and Amoako-Adu and Smith (2001) for the Canadian firms.

2 See the article The Big Number by Kristin Lin in the Wall Street Journal, August 18, 2015.

3 See the article Dual-Class Shares, A Two-Edged Sword by John Bussey in the Wall Street Journal, August 19, 2011. 
Among the dual-class firms, a small number of them have both their SV and IV shares publicly listed and traded. The publicly available SV shares tend to be less liquid than their IV counterparts, and yet they tend to be transacted at higher prices. The price premium of SV shares is mainly ascribed to their SV power. For example, Brown-Forman, a whisky and wine maker, currently has both SV (Class A, one vote per share) and IV (Class B, non-voting shares) common stock shares. On June 30, 2015, the SV shares traded at \$111.42, an 11\% premium to $\$ 100.18$ for the IV shares. Meanwhile, the SV shares were less liquid than the IV shares, with daily volume of 0.14 vs. 0.63 million shares.

However, some SV shares, though with SV power, trade at lower prices than their IV counterparts. During the 2009 financial crisis, Blockbuster, a DVD rental chain, had both SV (Class B, two votes per share) and IV (Class A, one vote per share) common stock shares. On January 13, 2009, the SV shares closed at a 25\% discount to its IV shares (\$1.02 vs. \$1.36). ${ }^{4}$ The illiquidity of SV (vs. IV) shares was mentioned as a cause of the price discount (e.g., daily volume of 0.4 vs. 2.3 million shares). This explanation appears insufficient, given that all firms' SV shares on average are less liquid than their IV counterparts.

According to the existing literature, both voting power and liquidity are pointed out as important factors affecting the price difference between SV and IV shares, but they seem inadequate to explain the big discount of Blockbuster's. In 2009, the voting power of Blockbuster's SV shares might have little worth since the firm did not perform well due to its noncompetitive or obsolete products/services (compared with Netflix) as well as the overall economic recession. Finally by 2010, Blockbuster delisted itself from the NYSE, and filed for Chapter 11 bankruptcy protection. Therefore, the power to control a firm is not only associated with the number of vote(s) that each SV share of common stock is entitled to, but also associated with two implications of control power: (1) how likely an outsider can accumulate a big block of SV shares in the market to gain the control; and (2) afterwards, how likely the firm can perform well. If it is difficult to accumulate enough SV shares in the market to gain the control, and/or if the firm does not and will not perform well, the voting power of SV shares is not much valuable or meaningful. In other words, what matters to SV shares is the actual control benefit that could be possibly achieved; and we can assess such control benefit by examining the two implications of control power.

This study is to illustrate and analyze the actual control benefit of SV shares by conducting three case analyses. The first case is about Farmer Mac, with a big price discount of SV vs. IV shares. The second case is about Fox, with a price similarity of SV vs. IV shares. The third case is about Heico, with a big price premium of SV vs. IV shares. Our findings are summarized as follows. First, in line with the existing studies, our three case analyses confirm that both voting power and liquidity help explain the price difference between SV and IV shares. In specific, voting power contributes to price premium effect of SV shares, while illiquidity contributes to price discount effect of SV shares. Second, the perception of the actual control benefit matters. On the one hand, when a firm's SV shares trade at a big discount to its IV shares, illiquidity may not be the only problem, while the lack of control benefit may be part of the cause. On the other hand, when a firm's SV shares trade at a big premium to its IV shares, there may be substantial control benefit, making the voting power very desirable.

The reminder of this paper is organized as follows. Section 2 conducts literature review. Section 3 discusses the data. Section 4 analyzes three cases. Finally, Section 5 concludes the paper.

${ }^{4}$ See the article To B Share or Not to B Share by Rick Aristotle Munarriz in the Motley Fool, January 14, 2009. 


\section{Literature Review}

Existing studies on SV and IV shares have chiefly covered three issues: (1) effect on firm value; (2) ownership structural changes; and (3) price differences. First, dual-class firms allow the divergence between insider voting rights and cash-flow rights, leading to increased extraction of private benefits of control and a decreased likelihood of takeover premium. Firm value decreases with the increase in the wedge between the voting rights and cash-flow rights (see Gompers et al., 2010; Masulis, Wang, \& Xie, 2009; Smart, Thirumalai, \& Zutter, 2008). ${ }^{5}$ However, under some special circumstances, the dual structure may increase firm value. At the IPOs, dual firms experience less underpricing than single-class firms (Smart \& Zutter, 2003).

Second, some firms combine their dual classes into a single class, while some others shift from a single class to dual classes. At the announcement of unification of dual classes into a single class, positive abnormal returns are observed (see Howell, 2008; Smart et al., 2008). In addition to economic reasons such as the increase in price or value, regulatory revisions may also drive the unifications, such as the SEC's severe limit on the ability of publicly traded firms to create dual-class capital structure by issuing SV shares in 1988, and the ban of new issues of IV stocks on the Tel Aviv Stock Exchange in Israel in 1990 (Hauser \& Lauterbach, 2004; Lauterbach \& Yafeh, 2011). At the creation of dual classes from a single class, however, the results are mixed: Partch (1987) showed unaffected shareholder wealth, Jarrell and Poulsen (1988) reported negative abnormal returns, and Dimitrov and Jain (2006) argued for value enhancement in the long term. Moreover, the creation of dual classes is also compared with other ownership transformations. Firms that consolidate their control through dual-class recapitalizations (vs. leveraged buyouts) have greater growth opportunities and lower agency costs (Lehn, Netter, \& Poulsen, 1990). Managers of dual-class firms tend to have higher ownership stakes than managers of firms with an employee stock ownership plan (Mikkelson \& Partch, 1994). Around stock splits, the shares become less liquid following a dual-class split, but more liquid following a matched regular stock split (Kim, Lin, Singh, \& Yu, 2007).

Third, the SV-IV price difference is usually manifested as the price premium of SV shares vs. IV shares. The premium, mainly driven by the voting power of SV shares, varies widely across countries, between $5 \%$ in the U.S. and 80\% in Italy (see Lease, McConnell, \& Mikkelson, 1983; 1984; Megginson, 1990; Zingales, 1994). ${ }^{6}$ In addition, Nenova (2003) provided an aggregate measure for the value of corporate voting rights for dual-class firms across 18 countries. The measure is $4.5 \%$ in common law countries, and $25.4 \%$ in French legal origin countries where investor protection is weaker. Doidge (2004) documented that the average voting premium is about $21 \%$ for dual-class foreign firms that do not cross-list in the U.S., and $12 \%$ for dual-class foreign firms with an American Depository Receipt (ADR) program.

Besides the difference in voting power, the SV shares seem less liquid than the IV shares. Overall, controlling shareholders tend not to trade shares actively. Megginson (1990) reported that for British dual firms, the SV shares are less frequently traded than the IV shares. Li, Ortiz-Molina, and Zhao (2008) documented that in more than $70 \%$ of the dual-class firms in the U.S., the SV shares are not publicly traded at all. For the SV shares that are traded, they are largely held by insiders. Gompers et al. (2010) pointed out that for most dual-class firms, the IV shares are publicly traded while the SV shares are non-traded. Out of all dual-class firms, only about $14 \%-20 \%$ have both classes of shares traded publicly.

\footnotetext{
${ }^{5}$ As Maury and Pajuste (2005) pointed out, families, which typically have managerial or board representation, are more prone to private benefit extraction if they are not monitored by another strong blockholder. A more equal distribution of votes among large blockholders has a positive effect on firm value.

${ }^{6}$ Barclay and Holderness (1989) stated that the price premium of block trades reflects the voting power of block trades.
} 
In summary, both voting power and liquidity are related to the price difference between SV and IV shares. According to Smith and Amoako-Adu (1995), on the one hand, voting power of the SV shares increases the SV price premium; on the other hand, higher liquidity of the IV shares is inversely related to the SV premium. As Schultz and Shive (2010) stated, prices of the SV and IV shares differ for rational reasons: the extra votes, or the extra liquidity.

Nevertheless, for SV shares, voting power does not always lead to price premium, and illiquidity can hardly be the major cause for price discount. Our study intends to explore the essence of SV shares: the actual control benefit that could be achieved.

\section{Data}

We employ the case analysis approach in this study because of two considerations. First, it is difficult to form a large sample of firms for our proposed topic. There are few dual-class firms that have both SV and IV shares listed and traded publicly, while most dual-class firms have privately held SV shares. Moreover, there are even fewer firms that have discounted SV shares. Second, the two implications of control power have not been intensively investigated yet by the current literature, and thus there are no standardized measures available. The case approach allows us to deal with unique features, data, and information flexibly.

We select three firms (Farmer Mac, Fox, and Heico) for our case analyses, each with both SV and IV common stock shares listed and traded publicly. The three firms represent three types of price relationship between SV and IV shares: Farmer Mac as a case of price discount, Fox as a case of price similarity, and Heico as a case of price premium. The SV and IV shares of each firm have the same earnings per share, the same dividend per share, and the same equity book value per share.

The data period is set as the most recent year: from July 1, 2014 to June 30, 2015. We collect data and other relevant information from Factset, 10-K reports, Standard \& Poor's NetAdvantage, publicly available websites (finance.yahoo.com; www.morningstar.com), etc.. Data regarding firm features, price relationship, voting power, liquidity, and share classes are from the most recent year (from July 1, 2014 to June 30, 2015). Data regarding firm performance are from the most recent 10 years (quarterly financial reports, June 2005 to March 2015; daily stock prices, from July 1, 2005 to June 30, 2015).

\section{Case Analyses}

\section{Firm Features and Price Relationship}

Table 1 provides firm features in Panel A and price relationship in Panel B for the three selected companies. The time period is from July 1, 2014 to June 30, 2015. The Federal Agricultural Mortgage Corporation ("Farmer Mac") is a stockholder-owned, federally chartered corporation, providing a secondary market for a variety of loans made to borrowers in rural America. Twenty-First Century Fox, Inc. is a diversified global media and entertainment company with operations in cable network programming, television, filmed entertainment, and direct broadcast satellite television. Heico Corporation is a leading manufacturer of Federal Aviation Administration ("FAA")-approved jet engine and aircraft component replacement parts, as well as various types of electronic equipment for various industries.

As Panel A of Table 1 shows, Farmer Mac belongs to the Credit Services industry of the Financial sector, and it is a small-cap and value-style firm. Fox belongs to the Media-Diversified industry of the Consumer Discretionary (or Consumer Cyclical) sector, and it is a large-cap and core-style firm. Heico belongs to the Aerospace \& Defense industry of the Industrials sector, and it is a mid-cap and growth-style firm. Hence, the 
three companies are very different in terms of business activity, size, and style. We notice that each firm has two classes of publicly traded common shares (SV and IV); additionally, Farmer Mac has a third class of common shares that are non-listed and have SV power. Shares Outstanding and Market Capitalization are observations at the end of the time period. We note that the SV shares of each firm tend to have lower number of shares outstanding and lower market capitalization than the IV shares.

In Panel B of Table 1, average close price is the mean of daily close prices. Price volatility is the standard deviation of daily close prices. Price diff is calculated as the difference between SV and IV close prices on the same day divided by the IV close price on that day, and the mean, median, minimum, and maximum of daily observations of price diff are reported. For Farmer Mac, the average price of its SV shares is much lower than that of its IV shares, with a mean price difference of $-20.9 \%$; thereby Farmer Mac is employed as a case of big price discount in this paper. For Fox, the average prices of its SV and IV shares are close, with a mean price difference of $-2.7 \%$; thereby Fox is used as a case of price similarity (or slight price discount). For Heico, the average price of its SV shares is much higher than that of its IV shares, with a mean price difference of 22.4\%; thereby Heico is used as a case of big price premium.

Table 1

Firm Features and Price Relationship

\begin{tabular}{|c|c|c|c|c|c|c|c|}
\hline \multicolumn{8}{|c|}{ Panel A: Firm features } \\
\hline Name & \multicolumn{2}{|l|}{ Sector/industry } & Cap/style & Ticker & Share class & $\begin{array}{l}\begin{array}{l}\text { Shares } \\
\text { outstanding } \\
\text { (million) }\end{array} \\
\end{array}$ & $\begin{array}{l}\text { Market cap } \\
\text { (\$ million) }\end{array}$ \\
\hline \multirow{3}{*}{$\begin{array}{l}\text { Federal } \\
\text { Agricultural } \\
\text { Mortgage } \\
\text { Corporation } \\
\text { (“Farmer } \\
\text { Mac”) }\end{array}$} & \multirow{3}{*}{\multicolumn{2}{|c|}{ Financial/credit services }} & \multirow{3}{*}{ Small/value } & Non-listed & $\begin{array}{l}\text { SV } \\
\text { (Class B) }\end{array}$ & 0.5 & - \\
\hline & & & & AGM.A & $\begin{array}{l}\text { SV } \\
\text { (Class A) }\end{array}$ & 1.0 & 29 \\
\hline & & & & AGM & $\begin{array}{l}\text { IV } \\
\text { (Class C) }\end{array}$ & 9.4 & 274 \\
\hline \multirow{2}{*}{$\begin{array}{l}\text { Twenty-First } \\
\text { Century Fox, } \\
\text { Inc. }\end{array}$} & \multirow{2}{*}{\multicolumn{2}{|c|}{$\begin{array}{l}\text { Consumer } \\
\text { discretionary/media-diversified }\end{array}$}} & \multirow{2}{*}{ Large/core } & FOX & $\begin{array}{l}\text { SV } \\
\text { (Class B) }\end{array}$ & 798.5 & 25,728 \\
\hline & & & & FOXA & $\begin{array}{l}\text { IV } \\
\text { (Class A) }\end{array}$ & $1,258.9$ & 40,978 \\
\hline \multirow{2}{*}{$\begin{array}{l}\text { Heico } \\
\text { Corporation }\end{array}$} & \multirow{2}{*}{\multicolumn{2}{|c|}{ Industrials/aerospace \& defense }} & \multirow{2}{*}{ Mid/growth } & HEI & $\begin{array}{l}\text { SV } \\
\text { (Common) }\end{array}$ & 26.9 & 1,564 \\
\hline & & & & HEI.A & $\begin{array}{l}\text { IV } \\
\text { (Class A) }\end{array}$ & 39.8 & 2,019 \\
\hline \multicolumn{8}{|c|}{ Panel B: Price relationship } \\
\hline Ticker & Share class & $\begin{array}{l}\text { Average close } \\
\text { price }(\$)\end{array}$ & $\begin{array}{l}\text { Price volatility } \\
\text { (\$) }\end{array}$ & $\begin{array}{l}\text { Price diff: } \\
\text { mean }\end{array}$ & $\begin{array}{l}\text { Price diff: } \\
\text { median }\end{array}$ & $\begin{array}{l}\text { Price diff: } \\
\text { min. }\end{array}$ & $\begin{array}{l}\text { Price diff: } \\
\text { max. }\end{array}$ \\
\hline AGM.A & SV & 24.14 & 1.92 & $-20.9 \%$ & $-21.2 \%$ & $-36.7 \%$ & $-1.7 \%$ \\
\hline AGM & IV & 30.51 & 1.81 & & & & \\
\hline FOX & SV & 33.52 & 1.23 & $-2.7 \%$ & $-2.9 \%$ & $-4.5 \%$ & $-0.1 \%$ \\
\hline FOXA & IV & 34.45 & 1.46 & & & & \\
\hline HEI & SV & 55.44 & 4.60 & $22.4 \%$ & $22.4 \%$ & $13.5 \%$ & $35.9 \%$ \\
\hline HEI.A & IV & 45.29 & 3.23 & & & & \\
\hline
\end{tabular}

Note. This table provides firm features in Panel A and price relationship in Panel B for three companies. The time period is from July 1, 2014 to June 30, 2015. In Panel A, all share classes are common stock share classes. Shares outstanding and market capitalization are at the end of the time period. In Panel B, average close price is the mean of daily close prices. Price volatility is the standard deviation of daily close prices. Price diff is calculated as the difference between SV and IV close prices on the same day divided by the IV close price on that day, and the mean, median, minimum, and maximum of daily observations of price diff are reported. 
Figure 1 presents the price difference in percentage (i.e., price diff) between SV and IV shares. As we observe, the daily price differences between SV and IV shares are distinctively different for the three companies. They are highly positive for Heico throughout the period, slightly negative for Fox during the entire period, and deeply negative for Farmer Mac throughout the period (but closer to $0 \%$ towards the end of the period). Given that the average price difference between SV and IV shares is about $5 \%$ in the U.S. (i.e., slight price premium), we will conduct an in-depth investigation of three cases: big price discount, price similarity (or slight price discount), and big price premium. We will analyze both the traditional explanations (voting power and liquidity) and our newly proposed explanations (two control power implications: share accumulation and firm performance).

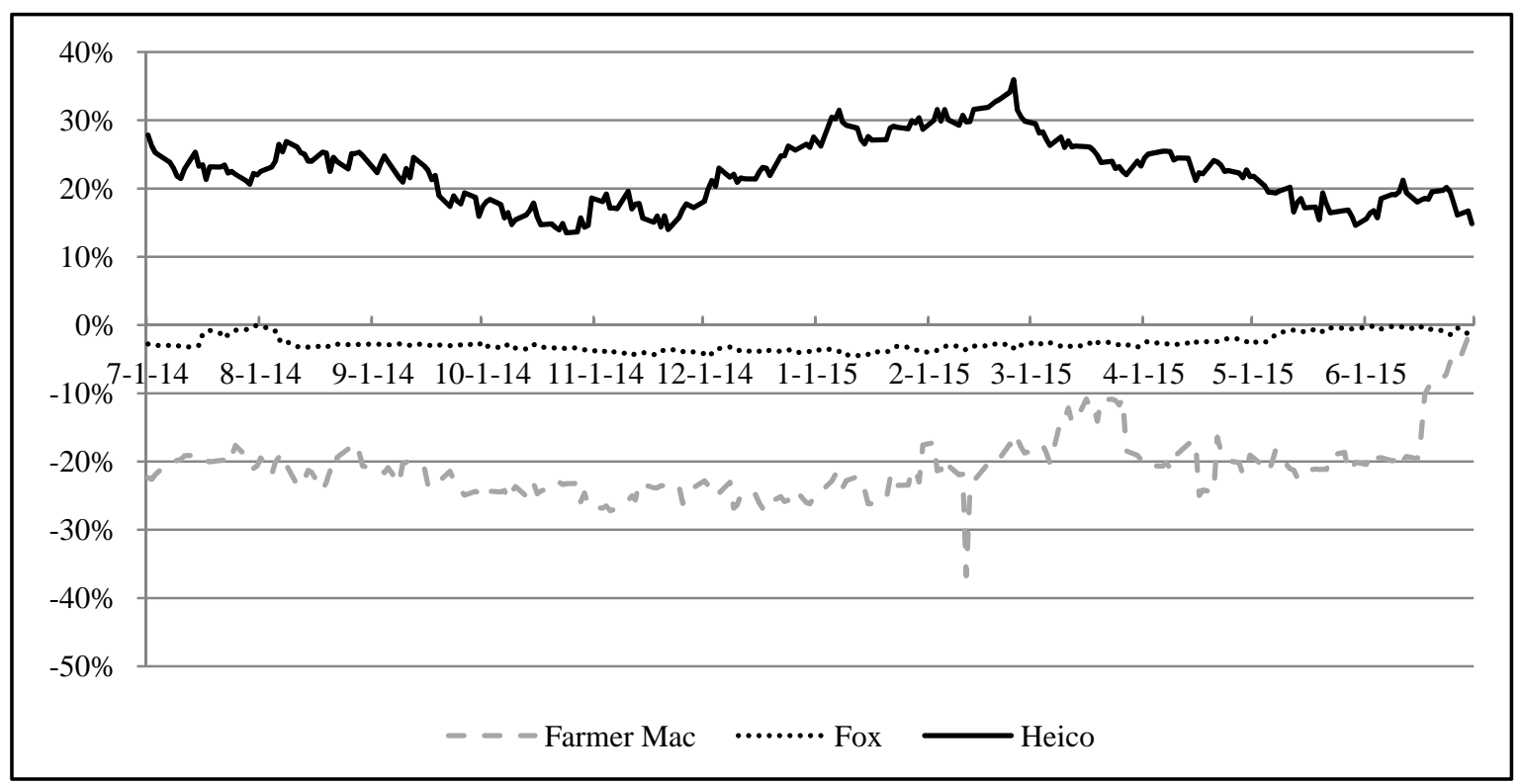

Figure $1^{7}$. Price relationship.

\section{Voting Power and Liquidity}

Existing literature has applied voting power and liquidity to the explanations of price premium of SV vs. IV shares. Table 2 reports the measures of voting power and liquidity for the three companies. Voting power is measured by number of vote(s) per share and vote\%, respectively. Vote\% is calculated as the total number of votes for a share class divided by the total number of votes for all common stock share classes. The results show that the voting power of SV shares greatly dominates that of IV shares for each of the three firms. In specific, Farmer Mac's two classes of SV shares have 100\% (i.e., 33\% plus 67\%) of votes; Farmer Mac's publicly traded SV shares, 67\%; Fox's SV shares, 100\%; and Heico's SV shares, 87\%. Obviously, the voting power measures do shed some lights on the big price premium for Heico, but do not help much to illustrate the big price discount for Farmer Mac or the price similarity (or slight price discount) for Fox. That is to say, in spite of the dominating voting power of SV shares, Farmer Mac's and Fox's SV shares are traded below their IV counterparts. This may imply that for Farmer Mac and Fox, the SV shareholders do not possess much control benefit, and thus their voting power is not much useful or valuable.

\footnotetext{
7 This figure presents price difference (in percentage) between SV and IV shares for three companies. The time period is from July 1, 2014 to June 30, 2015. The price difference (in percentage) is calculated as the difference between SV and IV close prices on the same day divided by the IV close price on that day.
} 
Liquidity is measured by average daily volume and daily share turnover, respectively. Daily share turnover is calculated as the average daily volume divided by shares outstanding. As we note, for Farmer Mac and Fox, the average daily volume and turnover are lower for SV shares than for IV shares, consistent with the usual situation that SV shares on average are less liquid than IV shares. The lower liquidity of SV shares surely contributes to the price discount of SV shares. For Heico, the average daily volume and turnover are higher for SV shares than for IV shares, certainly contributing to the price premium of SV shares. However, "higher liquidity" is not a must-have condition for price premium. All SV shares in the U.S. on average are traded 5\% above IV shares, but are less liquid than IV shares. As we mentioned previously, Brown-Forman's SV shares are traded at a premium of $11 \%$, but are less liquid than their IV counterparts. Therefore, although liquidity does contribute to the price difference between SV and IV shares, it might not be a major cause.

In sum, the price premium of SV vs. IV shares largely denotes a payment for the actual control benefit that the current and potential SV shareholders may achieve. Since measures of voting power and liquidity seem not enough to fully illustrate various cases of price difference between SV and IV shares, we suggest to examine two control power implications (share accumulation and firm performance). These two implications are likely to reveal whether SV shareholders possess much or little control benefit, and hence whether SV shares are traded at a premium or discount.

Table 2

Voting Power and Liquidity

\begin{tabular}{lllrrl}
\hline Ticker & Share class & $\begin{array}{l}\text { No. of vote(s) per } \\
\text { share }\end{array}$ & Vote\% & $\begin{array}{l}\text { Average daily } \\
\text { volume (shares) }\end{array}$ & Daily share turnover \\
\hline Non-listed & SV & 1 & $33 \%$ & - & - \\
AGM.A & SV & 1 & $67 \%$ & 390 & $0.04 \%$ \\
AGM & IV & 0 & $0 \%$ & 37,246 & $0.39 \%$ \\
FOX & SV & 1 & $100 \%$ & $3,924,737$ & $0.49 \%$ \\
FOXA & IV & 0 & $0 \%$ & $13,676,719$ & $1.09 \%$ \\
HEI & SV & 1 & $87 \%$ & 193,769 & $0.72 \%$ \\
HEI.A & IV & 0.1 & $13 \%$ & 65,411 & $0.16 \%$ \\
\hline
\end{tabular}

Note. This table reports voting power and liquidity measures for three companies. The time period is from July 1, 2014 to June 30, 2015. Vote\% is calculated as the total number of votes for a share class divided by the total number of votes for all common stock share classes. Daily share turnover is calculated as the average daily volume divided by shares outstanding.

\section{Control Power Implication 1: Share Accumulation}

Other than the number of vote(s) per share, the control power of SV shares can be revealed by examining whether an outsider can accumulate a big block of SV shares in the market to gain the control, and whether the firm can perform well afterwards.

Table 3 provides information regarding whether it is easy or difficult to accumulate enough SV shares in the market for control. First, the number of registered holders ranges from 396 to 1,400 for publicly traded SV shares and from 399 to 36,400 for IV shares. In addition, there are only 77 holders for the non-listed SV shares of Farmer Mac. Thus, each firm's public SV holders seem numerous enough for making a market.

Second, the float (in percentage) ranges from $49 \%$ to $76 \%$ for SV shares and from $90 \%$ to $99 \%$ for IV shares. Thus, SV shares have lower float than IV shares for each of the three firms. Regarding SV shares, the lower the float, the more difficult it is for an outsider to accumulate enough shares in the market for control. Among the three firms, Fox's SV shares have the lowest float (49\%), Farmer Mac's public SV shares are in the middle (61\%), and Heico's SV shares have the highest float (76\%). 
Third, if SV shares are concentrated in one largest holder, it may be difficult for an outsider to accumulate enough shares in the market for control. Among the three firms, Fox's SV shares are the most concentrated (39\%), Farmer Mac's public SV shares are in the middle (31\%), and Heico's SV shares are the least concentrated (10\%). In addition, Farmer Mac's non-listed SV shares are concentrated in a few largest holders, and its public SV shares have a requirement: each holder cannot exceed 33\% shares of this class. That is, in order to obtain more than $50 \%$ of votes for control, an outsider has to accumulate Farmer Mac's SV shares from two SV classes (publicly listed/traded and non-listed).

Overall, when an outsider attempts to obtain control power of a firm, it seems less difficult to accumulate Heico's SV shares in the market to have more than 50\% of votes, but more difficult to accumulate Fox's and Farmer Mac's SV shares. Thus, Heico's SV share accumulation is more likely to lead to control than Fox's and Farmer Mac's. The results generally support the big price premium for Heico, the slight price discount for Fox, and the big price discount for Farmer Mac. Nevertheless, share accumulation cannot stand alone as a decisive factor for various cases of price difference; rather, it has to be analyzed together with firm performance. After all, if an outsider cannot accumulate enough float SV shares in the market to obtain control, the outsider can always negotiate with the insiders to buy the non-float (and even the non-listed) SV shares.

Table 3

Control Power Implication 1: Share Accumulation

\begin{tabular}{|c|c|c|c|c|}
\hline Ticker & Share class & $\begin{array}{l}\text { No. of } \\
\text { registered } \\
\text { holders }\end{array}$ & Float & Largest holder(s) \\
\hline Non-listed & SV & 77 & - & $97 \%$ shares of this class are held by five holders. \\
\hline AGM.A & SV & 1,008 & $61 \%$ & $\begin{array}{l}\text { Each holder cannot exceed 33\% shares of this class. } \\
\text { The largest holder has about 31\% shares of this class. }\end{array}$ \\
\hline AGM & IV & 941 & $97 \%$ & \\
\hline FOX & SV & 1,400 & $49 \%$ & The largest holder (Murdoch Family Trust) has about 39\% shares of this class. \\
\hline FOXA & IV & 36,400 & $99 \%$ & \\
\hline HEI & SV & 396 & $76 \%$ & The largest holder has about $10 \%$ shares of this class. \\
\hline HEI.A & IV & 399 & $90 \%$ & \\
\hline
\end{tabular}

Note. This table provides information regarding whether it is easy or difficult to accumulate enough SV shares for control. The time period is from July 1, 2014 to June 30, 2015.

\section{Control Power Implication 2: Firm Performance}

Table 4 provides information about firm performance of one, five, and 10 years in Panels A, B, and C, respectively, and stock ratings in Panel D. The time period ends on June 30, 2015. P/E, P/B, Div Yield, Sales Growth, NI Growth, Div Growth, ROE, and Debt Ratio are the average of quarterly reported data from Factset. Price Growth is calculated as the annual return based on the beginning and ending close prices. ROE VOLA is the standard deviation of quarterly reported ROE data. Debt Ratio refers to the total-debt-to-total-assets ratio. We categorize the firm performance measures into four groups: Valuation, Growth, Return, and Leverage. Valuation includes P/E, P/B, and Div Yield. Growth includes Price Growth, Sales Growth, NI Growth, and Div Growth. Return includes ROE and ROE VOLA. Leverage includes Debt Ratio. Stock ratings are around the end of the time period. Factset Average Rating provides analyst recommendations ranging from 1 (buy) to 5 (sell). S\&P Quality Ranking attempts to capture the growth and stability of earnings and dividends, based on per-share earnings and dividends records of the most recent 10 years; and it ranges from A+ (high quality) to D (low quality). S\&P Investability Quotient (IQ) Percentile serves as an indicator of potential medium-to-long-term return and as a caution against downside risk, and it ranges from $100 \%$ (best) to $1 \%$ (worst). 
Firm performance in one year. Panel A of Table 4 reports performance results of the past one year. Farmer Mac's P/E and P/B ratios are much lower than the S\&P 500 Index and its Div Yield ratios are close to the index, manifesting the value style of the firm. Farmer Mac's growth rates of sales, net income, and dividends are higher than the S\&P 500 Index, which appears contradictory to the value style. This is probably because the one-year data are too short to decide the style. In addition, Farmer Mac's SV shares increased in price, but its IV shares decreased in price, leading to a smaller discount for SV shares towards the end of the one-year period (see Figure 1). Farmer Mac's ROE is lower than the S\&P 500 Index and its ROE VOLA is close to the index, indicating lower profitability for common equity holders. Farmer Mac's Debt Ratio is much higher than the S\&P 500 Index, reflecting the high-leverage feature of financial firms (No credit rating is available for Farmer Mac).

Fox's P/E, P/B, and Div Yield ratios show mixed patterns when they are compared with the S\&P 500 Index, implying the core style of the firm. Fox's growth rates of sales, net income, and dividends also show mixed patterns when they are compared with the index. In addition, both SV and IV shares decreased in price, keeping a slight price discount for SV shares throughout the one-year period (see Figure 1). Fox's ROE is much higher than the S\&P 500 Index and its ROE VOLA is also much higher than the index, indicating higher but more volatile profitability for common equity holders. Fox's Debt Ratio is higher than the S\&P 500 Index, suggesting higher leverage (its credit rating is $\mathrm{BBB}+$ at the end of the one-year period).

Heico's P/E and P/B ratios are much higher than the S\&P 500 Index and its Div Yield ratios are much lower than the index, displaying the growth style of the firm. Heico's growth rates of sales, net income, and dividends show mixed patterns when they are compared with the index. In addition, both SV and IV shares increased in price, keeping a premium for SV shares during the one-year period (see Figure 1). Heico's ROE is higher than the S\&P 500 Index and its ROE VOLA is close to the index, indicating higher profitability for common equity holders. Heico's Debt Ratio is close to the S\&P 500 Index (no credit rating is available for Heico).

Firm performance in five years. Panel $B$ of Table 4 reports performance results of the past five years. Farmer Mac's valuation measures display the same patterns as in Panel A, and they are in line with the value style of the firm. Farmer Mac's growth rates of stock price, sales, net income, and dividends show mixed patterns when they are compared with the S\&P 500 Index. Farmer Mac's ROE is lower than the S\&P 500 Index, but its ROE VOLA is much higher than the index, indicating lower and more volatile profitability. Farmer Mac's Debt Ratio demonstrates the same pattern as in Panel A.

Fox's P/E and P/B ratios are higher than the S\&P 500 Index, and its Div Yield ratios are lower than the index, implying the core-to-mild-growth style of the firm. Fox's growth rates of stock price, sales, net income, and dividends present mixed patterns when they are compared with the index. Fox's return measures show the same patterns as in Panel A, i.e., higher but more volatile profitability. Fox's Debt Ratio also shows the same pattern as in Panel A.

Heico's valuation measures show the same patterns as in Panel A, and they match the growth style of the firm. Heico's growth rates of stock price, sales, net income, and dividends are all higher than the index, confirming the growth style of the firm. Heico's ROE is close to the S\&P 500 Index and its ROE VOLA is higher than the index, indicating similar but more volatile profitability. Heico's debt ratio is lower than the S\&P 500 Index, implying lower leverage. 
Table 4

Control Power Implication 2: Firm Performance

\begin{tabular}{|c|c|c|c|c|c|c|c|c|c|c|c|}
\hline \multicolumn{12}{|c|}{ Panel A: Firm performance in one year } \\
\hline \multirow[b]{2}{*}{ Ticker } & \multirow{2}{*}{$\begin{array}{l}\text { Share } \\
\text { class }\end{array}$} & \multicolumn{3}{|c|}{ Valuation } & \multicolumn{4}{|c|}{ Growth } & \multicolumn{2}{|c|}{ Return } & \multirow{2}{*}{$\begin{array}{l}\text { Leverage } \\
\text { Debt ratio }\end{array}$} \\
\hline & & $\mathrm{P} / \mathrm{E}$ & $\mathrm{P} / \mathrm{B}$ & Div yield & $\begin{array}{l}\begin{array}{l}\text { Price } \\
\text { growth }\end{array} \\
\text {. }\end{array}$ & $\begin{array}{l}\text { Sales } \\
\text { growth }\end{array}$ & $\begin{array}{l}\text { NI } \\
\text { growth }\end{array}$ & $\begin{array}{l}\text { Div } \\
\text { growth }\end{array}$ & ROE & $\begin{array}{l}\text { ROE } \\
\text { VOLA }\end{array}$ & \\
\hline \multicolumn{2}{|l|}{ S\&P 500} & 17.5 & 2.7 & $1.9 \%$ & $4.6 \%$ & $3.0 \%$ & $5.2 \%$ & $12.6 \%$ & $15.5 \%$ & $0.3 \%$ & $22.9 \%$ \\
\hline AGM.A & SV & 6.4 & 0.8 & $2.4 \%$ & $13.5 \%$ & $21.2 \%$ & $31.6 \%$ & $16.1 \%$ & $11.2 \%$ & $0.8 \%$ & \multirow[t]{2}{*}{$85.0 \%$} \\
\hline AGM & IV & 8.1 & 1.0 & $1.9 \%$ & $-8.4 \%$ & \multirow{3}{*}{$2.7 \%$} & \multirow{3}{*}{$140.3 \%$} & & & & \\
\hline FOX & SV & 12.7 & 4.1 & $0.8 \%$ & $-5.4 \%$ & & & $10.0 \%$ & \multirow[t]{2}{*}{$37.0 \%$} & $16.1 \%$ & \multirow[t]{2}{*}{$36.3 \%$} \\
\hline FOXA & IV & 13.1 & 4.3 & $0.7 \%$ & $-7.1 \%$ & & & & & & \\
\hline HEI & SV & 30.4 & 5.2 & $0.2 \%$ & $9.8 \%$ & \multirow[t]{2}{*}{$3.6 \%$} & \multirow[t]{2}{*}{$10.1 \%$} & $11.9 \%$ & \multirow[t]{2}{*}{$18.6 \%$} & $0.4 \%$ & \multirow[t]{2}{*}{$22.7 \%$} \\
\hline HEI.A & IV & 24.8 & 4.2 & $0.3 \%$ & $22.2 \%$ & & & & & & \\
\hline \multicolumn{12}{|c|}{ Panel B: Firm performance in five years } \\
\hline \multirow[b]{2}{*}{ Ticker } & \multirow{2}{*}{$\begin{array}{l}\text { Share } \\
\text { class }\end{array}$} & \multicolumn{3}{|c|}{ Valuation } & \multicolumn{4}{|c|}{ Growth } & \multicolumn{2}{|c|}{ Return } & Leverage \\
\hline & & $\mathrm{P} / \mathrm{E}$ & $\mathrm{P} / \mathrm{B}$ & Div yield & $\begin{array}{l}\begin{array}{l}\text { Price } \\
\text { growth }\end{array} \\
\end{array}$ & $\begin{array}{l}\text { Sales } \\
\text { growth }\end{array}$ & $\begin{array}{l}\text { NI } \\
\text { growth }\end{array}$ & $\begin{array}{l}\text { Div } \\
\text { growth }\end{array}$ & ROE & $\begin{array}{l}\text { ROE } \\
\text { VOLA }\end{array}$ & $\overline{\text { Debt ratio }}$ \\
\hline S\&P 500 & & 15.1 & 2.3 & $1.9 \%$ & $15.0 \%$ & $5.0 \%$ & $17.8 \%$ & $11.9 \%$ & $15.2 \%$ & $0.7 \%$ & $23.7 \%$ \\
\hline AGM.A & SV & 7.4 & 0.8 & $1.9 \%$ & $22.0 \%$ & $10.0 \%$ & $-25.5 \%$ & $28.0 \%$ & $12.5 \%$ & $5.2 \%$ & $89.1 \%$ \\
\hline AGM & IV & 9.5 & 1.0 & $1.5 \%$ & $18.1 \%$ & & & & & & \\
\hline FOX & SV & 16.3 & 2.8 & $0.8 \%$ & $22.7 \%$ & $-0.2 \%$ & $51.1 \%$ & $16.9 \%$ & $18.6 \%$ & $12.9 \%$ & $29.1 \%$ \\
\hline FOXA & IV & 16.0 & 2.8 & $0.9 \%$ & $26.4 \%$ & & & & & & \\
\hline HEI & SV & 29.9 & 4.5 & $0.2 \%$ & $27.5 \%$ & $15.4 \%$ & $22.3 \%$ & $21.5 \%$ & $15.7 \%$ & $2.5 \%$ & $15.2 \%$ \\
\hline HEI.A & IV & 22.5 & 3.4 & $0.3 \%$ & $32.2 \%$ & & & & & & \\
\hline & & & & Pane & C: Firm p & rformance & in 10 years & & & & \\
\hline S\&P 500 & & 15.5 & 2.3 & $2.0 \%$ & $5.6 \%$ & $5.4 \%$ & $9.7 \%$ & $9.3 \%$ & $15.2 \%$ & $2.2 \%$ & $25.5 \%$ \\
\hline AGM.A & SV & 8.0 & 0.9 & $2.8 \%$ & $8.1 \%$ & & & & & & \\
\hline AGM & IV & 10.9 & 1.2 & $2.2 \%$ & $4.6 \%$ & $9.3 \%$ & $-75.4 \%$ & $9.5 \%$ & $6.2 \%$ & $22.2 \%$ & $90.5 \%$ \\
\hline FOX & SV & 18.1 & 2.2 & $0.8 \%$ & $8.9 \%$ & $3.6 \%$ & $11.1 \%$ & $18.2 \%$ & $12.8 \%$ & $13.3 \%$ & $25.8 \%$ \\
\hline FOXA & IV & 17.4 & 2.2 & $0.9 \%$ & $9.6 \%$ & & & & & & \\
\hline HEI & SV & 28.4 & 3.5 & $0.2 \%$ & $20.6 \%$ & $17.8 \%$ & $19.9 \%$ & $30.4 \%$ & $13.3 \%$ & $3.1 \%$ & $11.8 \%$ \\
\hline HEI.A & IV & 22.1 & 2.7 & $0.3 \%$ & $22.5 \%$ & & & & & & \\
\hline & & & & & Panel D & Stock ra & & & & & \\
\hline Ticker & & & hare class & & $\begin{array}{l}\text { Factset } \\
\text { average r } \\
(1 \text { to } 5)\end{array}$ & ting & $\begin{array}{l}S \& P \\
(A+t\end{array}$ & $\begin{array}{l}\text { quality ran } \\
\text { o D) }\end{array}$ & & $\begin{array}{l}\text { X IQ pe } \\
00 \% \text { to } 1\end{array}$ & ntile \\
\hline AGM.A & & & V & & 1.00 & & B & & & & \\
\hline AGM & & & V & & 1.00 & & B- & & & $\%$ & \\
\hline FOX & & & V & & 1.17 & & N.A. & & & A. & \\
\hline FOXA & & & V & & 1.29 & & $\mathrm{~B}+$ & & & $\%$ & \\
\hline HEI & & & V & & 1.50 & & A & & & $\%$ & \\
\hline HEI.A & & & $V$ & & 1.50 & & A & & & $\%$ & \\
\hline
\end{tabular}

Note. This table provides information about firm performance of one, five, and 10 years in Panels A, B, and C respectively, and stock ratings in Panel D. The time period ends on June 30, 2015. P/E, P/B, div yield, sales growth, NI growth, div growth, ROE, and debt ratio are the average of quarterly reported data from Factset. Price growth is calculated as the annual return based on the beginning and ending close prices. ROE VOLA is the standard deviation of quarterly reported ROE data. Debt ratio refers to the total-debt-to-total-assets ratio. Stock ratings are around the end of the time period. Factset average rating provides recommendations ranging from 1 (buy) to 5 (sell). S\&P Quality Ranking attempts to capture the growth and stability of earnings and dividends, based on per-share earnings and dividends records of the most recent 10 years; and it ranges from A+ (high quality) to D (low quality). S\&P IQ percentile serves as an indicator of potential medium-to-long-term return and as a caution against downside risk, and it ranges from $100 \%$ (best) to $1 \%$ (worst). 
Firm performance in 10 years. Panel $C$ of Table 4 reports performance results of the past 10 years. Farmer Mac's valuation measures display the same patterns as in Panels A and B, and they are in line with the value style of the firm. Farmer Mac's growth rates of stock price, sales, net income, and dividends show mixed patterns when they are compared with the S\&P 500 Index. Farmer Mac's ROE is much lower than the S\&P 500 Index, but its ROE VOLA is much higher than the index, indicating lower and more volatile profitability in the past 10 years. Farmer Mac's debt ratio demonstrates the same pattern as in Panels A and B.

Fox's valuation measures show mixed patterns when they are compared with the S\&P 500 Index, implying the core style of the firm. Fox's growth measures also show mixed patterns. Fox's ROE is lower than the S\&P 500 Index, but its ROE VOLA is much higher than the index, indicating lower and more volatile profitability in the past 10 years. Fox's Debt Ratio is close to the index.

Heico's valuation measures show the same patterns as in Panels A and B, and they match the growth style of the firm. Heico's growth rates of stock price, sales, net income, and dividends are all much higher than the index in the past 10 years, confirming the growth style of the firm. Heico's ROE is slightly lower than the S\&P 500 Index, and its ROE VOLA is slightly higher than the index, indicating similar profitability in the past 10 years. Heico's debt ratio is much lower than the S\&P 500 Index, implying lower leverage.

Among the three firms, Heico has the best performance (the highest growth and the best profitability) in the past 10 years, Fox is in the middle, and Farmer Mac has the worst performance. Although past performance does not guarantee the future, it does help to gauge the future performance and the expected control benefit. Heico's good long-term performance may support substantial control benefit and hence price premium of SV (vs. IV) shares, Fox's ordinary long-term performance may suggest limited control benefit and hence price similarity of SV and IV shares, and Farmer Mac's bad long-term performance may reveal little or no control benefit and hence price discount of SV (vs. IV) shares.

Stock ratings. Panel C of Table 4 reports stock ratings for the three firms. The Factset average rating is close to 1 (buy) for each of the three firms. Farmer Mac, with the worst long-term performance and lowest valuation multiples (P/E and $\mathrm{P} / \mathrm{B})$, has the strongest buy recommendation, indicating a possible turn for better performance in the future. Fox, with the ordinary long-term performance and market-average valuation multiples, has a strong buy recommendation, indicating a good performance in the future. Heico, with the best long-term performance and highest valuation multiples, has a buy recommendation, indicating a continuously good performance in the future. Since the Factset average rating tends to concentrate on the short term, it does not help much to explain the control benefit as well as the variation of price difference between SV and IV shares.

The S\&P quality ranking and the S\&P IQ percentile are for the long term. Among the three firms, Heico has the highest quality ranking (in terms of growth and stability of earnings and dividends) and the highest IQ percentile (in terms of potential return and caution against downside risk). Fox is in the middle. ${ }^{8}$ Farmer Mac has the lowest quality ranking and the lowest IQ percentile. The results of quality ranking and IQ are largely consistent with the results in Panel C. That is, Heico's high quality and high IQ may support substantial control benefit and big price premium of SV shares. Fox's ordinary quality and ordinary IQ may be in line with mild control benefit and price similarity of SV and IV shares. Farmer Mac's low quality and low IQ may suggest lack of control benefit and big price discount of SV shares.

${ }^{8}$ There is no S\&P report available for FOX. The quality ranking and IQ of FOX are expected to be close to FOXA. 
We need to clarify three issues about firm performance. First, our firm performance measures in Table 4 are selective rather than inclusive. Second, the historical performance measures are affected by all kinds of factors, including firm-specific, industrial, sector, macroeconomic, policy, etc.. Third, it is important to guess/assess the future performance, and this is a difficult task because the past performance does not guarantee the future. For example, around the end of our study period, the Federal Reserve was expected to raise the fed fund rate from zero to a higher level in the near future, which may be good news for turning around financial firms such as Farmer Mac. Another example is that if a firm's SV and IV classes are going to be unified, the price difference between them may get close to $0 \%$.

\section{Conclusions}

We analyze the price difference between SV and IV shares for three dual-class firms: Farmer Mac as a big price discount case, Fox as a price similarity case, and Heico as a big price premium case. Consistent with the existing literature, our three cases show that both voting power and liquidity help explain the SV-IV price difference. In addition, we suggest the examination of control benefit. Specifically, the big price discount of Farmer Mac's SV (vs. IV) shares may result from the lack of control benefit, manifested by difficult SV-share accumulation in the market and bad long-term firm performance, besides the low liquidity of its SV shares. The price similarity of Fox's SV and IV shares may be explained by the offsetting effects of price premium due to control benefit and price discount due to low liquidity. The big price premium of Heico's SV (vs. IV) shares may come from the substantial control benefit, revealed by easy SV-share accumulation in the market and good long-term firm performance, besides the high liquidity of its SV shares.

\section{References}

Amoako-Adu, B., \& Smith, B. F. (2001). Dual class firms: Capitalization, ownership structure and recapitalization back into single class. Journal of Banking \& Finance, 25(6), 1083-1111.

Barclay, M. J., \& Holderness, C. G. (1989). Private benefits from control of public corporations. Journal of Financial Economics, 25(2), 371-395.

DeAngelo, H., \& DeAngelo, L. (1985). Managerial ownership of voting rights: A study of public corporations with dual classes of common stock. Journal of Financial Economics, 14(1), 33-69.

Dimitrov, V., \& Jain, P. C. (2006). Recapitalization of one class of common stock into dual-class: Growth and long-run stock returns. Journal of Corporate Finance, 12(2), 342-366.

Doidge, C. (2004). U.S. cross-listings and the private benefits of control: Evidence from dual-class firms. Journal of Financial Economics, 72(3), 519-533.

Gompers, P. A., Ishii, J., \& Metrick, A. (2010). Extreme governance: An analysis of dual-class firms in the United States. Review of Financial Studies, 23(3), 1051-1088.

Hauser, S., \& Lauterbach, B. (2004). The value of voting rights to majority shareholders: Evidence from dual-class stock unifications. Review of Financial Studies, 17(4), 1167-1184.

Howell, J. W. (2008). No more share classes: A study of U.S. dual class stock unifications. Working Paper.

Jarrell, G. A., \& Poulsen, A. B. (1988). Dual-class recapitalizations as antitakeover mechanisms: The recent evidence. Journal of Financial Economics, 20, 129-152.

Kim, J., Lin, J. C., Singh, A., \& Yu, W. (2007). Dual-class stock splits and liquidity. Working Paper.

Lauterbach, B., \& Yafeh, Y. (2011). Long term changes in voting power and control structure following the unification of dual class shares. Journal of Corporate Finance, 17(2), 215-228.

Lease, R. C., McConnell, J. J., \& Mikkelson, W. H. (1983). The market value of control in publicly-traded corporations. Journal of Financial Economics, 11(1-4), 439-471.

Lease, R. C., McConnell, J. J., \& Mikkelson, W. H. (1984). The market value of differential voting rights in closely held corporations. Journal of Business, 57(4), 443-467. 
Lehn, K., Netter, J., \& Poulsen, A. (1990). Consolidating corporate control: Dual-class recapitalizations versus leveraged buyouts. Journal of Financial Economics, 27(2), 557-580.

Li, K., Ortiz-Molina, H., \& Zhao, X. (2008). Do voting rights affect institutional investment decisions? Evidence from dual-class firms. Financial Management, 37(4), 713-745.

Loughran, T., \& Ritter, J. (2004). Why has IPO underpricing changed over time? Financial Management, 33(3), 5-37.

Masulis, R. W., Wang, C., \& Xie, F. (2009). Agency problems at dual-class companies. Journal of Finance, 64(4), 1697-1727.

Maury, B., \& Pajuste, A. (2005). Multiple large shareholders and firm value. Journal of Banking \& Finance, 29(7), $1813-1834$.

Megginson, W. L. (1990). Restricted voting stock, acquisition premiums, and the market value of corporate control. Financial Review, 25(2), 175-198.

Mikkelson, W. H., \& Partch, M. M. (1994). The consequences of unbundling managers' voting rights and equity claims. Journal of Corporate Finance, 1(2), 175-199.

Nenova, T. (2003). The value of corporate voting rights and control: A cross-country analysis. Journal of Financial Economics, 68(3), 325-351.

Partch, M. M. (1987). The creation of a class of limited voting common stock and shareholder wealth. Journal of Financial Economics, 18(2), 313-339.

Schultz, P., \& Shive, S. (2010). Mispricing of dual-class shares: Profit opportunities, arbitrage, and trading. Journal of Financial Economics, 98(3), 524-549.

Smart, S. B., \& Zutter, C. J. (2003). Control as a motivation for underpricing: A comparison of dual and single-class IPOs. Journal of Financial Economics, 69(1), 85-110.

Smart, S. B., Thirumalai, R. S., \& Zutter, C. J. (2008). What's in a vote? The short- and long-run impact of dual-class equity on IPO firm values. Journal of Accounting \& Economics, 45(1), 94-115.

Smith, B. F., \& Amoako-Adu, B. (1995). Relative prices of dual class shares. Journal of Financial \& Quantitative Analysis, 30(2), 223-239.

Zingales, L. (1994). The value of the voting right: A study of the Milan Stock Exchange experience. Review of Financial Studies, $7(1), 125-148$. 